\title{
Pilibacter termitis gen. nov., sp. nov., a lactic acid bacterium from the hindgut of the Formosan subterranean termite (Coptotermes formosanus)
}

Correspondence
Claudia Husseneder
chusseneder@agcenter.Isu.edu

\author{
Dennis T. Higashiguchi, ${ }^{1}$ Claudia Husseneder, ${ }^{1}$ J. Kenneth Grace ${ }^{2}$ \\ and John M. Berestecky ${ }^{3}$
'Department of Entomology, Louisiana State University Agricultural Center, 404 Life Sciences Building, Baton Rouge, LA 70803, USA
${ }^{2}$ Department of Plant and Environmental Protection Sciences, University of Hawaii at Manoa, Honolulu, HI, USA
${ }^{3}$ Department of Math and Sciences, Kapiolani Community College, Honolulu, HI, USA

A previously undescribed anaerobic, heterofermentative, non-spore-forming, Gram-positive rod was isolated from the hindgut of the Formosan subterranean termite Coptotermes formosanus Shiraki. The DNA G $+C$ content of this bacterium was $37.8 \mathrm{~mol} \%$. Sequence analysis of the $16 \mathrm{~S}$ rRNA gene revealed that this organism is related to, but distinct from, several genera of lactic acid bacteria, principally several species of the genus Enterococcus. Phenotypic traits that serve to separate this organism from related genera include high levels of the cellular fatty acid C18: $1 \omega 9 c$ and the production of ethanol along with lactic acid as fermentation products. Based on the collected phylogenetic and phenotypic evidence, it is proposed that the unknown organism represents a novel species in a new genus, Pilibacter termitis gen. nov., sp. nov. The type strain is

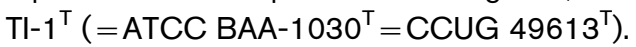

It has been demonstrated that the guts of termites house a diverse collection of bacteria encompassing several disparate phyla and even a novel phylum (Ohkuma \& Kudo, 1996). However, the majority of the microbial population is thought to be recalcitrant to isolation in the laboratory. Despite this problem, there remains a considerable population of bacteria in termites which may be isolated and characterized using conventional bacteriological techniques. An example includes bacteria of the order 'Lactobacillales', which have been recovered from several different species of termites, including Mastotermes darwiniensis, Cryptotermes primus, Heterotermes ferox, Coptotermes lacteus, Schedorhinotermes intermedius, Nasutitermes exitiosus (Eutick et al., 1978), Reticulitermes flavipes (Schultz \& Breznak, 1978; Bauer et al., 2000), Nasutitermes arborum, Thoracotermes macrothorax and Anoplotermes pacificus (Bauer et al., 2000). Many of the endemic bacteria associated with the termite hindgut, such as species of the genus Bacteroides, Desulfovibrio termitidis and Acetonema longum, readily utilize lactic acid as a carbon source (Schultz \& Breznak, 1979; Trinkerl et al., 1990; Kane \& Breznak, 1991). Therefore, it is feasible that the lactic acid bacteria play an

Abbreviations: DMA, dimethyl aldehyde; PYR, L-pyrrolidonyl $\beta$-naphthylamide.

The GenBank/EMBL/DDBJ accession number for the 16S rRNA gene sequence of strain $\mathrm{TI}-1^{\top}$ is $\mathrm{AY} 533171$. important role in maintaining the homeostasis of the bacterial community associated with the termite hindgut. In this paper, we report the isolation of a member of a new genus of lactic acid bacteria isolated from the gut of Coptotermes formosanus Shiraki (Isoptera: Rhinotermitidae).

Workers of the termite species Coptotermes formosanus were obtained from three separate colonies on the campus of the University of Hawaii at Manoa. The termites were divided into three treatment groups for study. The first group was dissected within $24 \mathrm{~h}$ of collection. The second group was maintained for 1 week on a diet of Douglas fir wafers in arenas of sand moistened with distilled water. The third group was maintained in Petri dish arenas and fed a diet of Whatman No. 3 filter paper for 1 week. Fifteen termites from each of the three treatment groups were selected for dissection, cultivation and enumeration of hind-gut bacteria.

Termites were surface sterilized with $80 \%$ ethanol. Using an aseptic technique, the hindgut was dissected and homogenized and the homogenate was subjected to serial dilutions and grown on Todd-Hewitt agar at $30{ }^{\circ} \mathrm{C}$ under anaerobic conditions using $\mathrm{H}_{2} / \mathrm{CO}_{2}$ Gas-Paks (BBL BectonDickinson). After 3 days of incubation, several strains of a Gram-positive rod with distinct irregular rod morphology were recovered. It was found that bacteria presenting the distinct irregular rod morphology comprised a large fraction of the recovered lactic acid bacteria: $31 \%$ of enumerated 
colonies from the immediately dissected termites, $12 \%$ of enumerated colonies from the laboratory-reared termites maintained on a wood diet and $19 \%$ of enumerated colonies from the laboratory-reared termites maintained on a filterpaper diet. Each of the irregular rod-shaped bacteria tested from the different termite treatment groups demonstrated similar profiles when subjected to standard bacteriological tests (i.e. acid from a variety of carbohydrates, aesculin hydrolysis, urea hydrolysis and nitrate reduction). Three of the irregular rod-shaped bacteria were selected on the basis of $16 \mathrm{~S}$ rRNA gene sequence analysis and subjected to further characterization. The first isolated bacterium from the immediately dissected group was designated termite isolate $1\left(\mathrm{TI}-1^{\mathrm{T}}\right)$. Strain TI-2 was isolated from the filter-paper-fed treatment group and strain TI-3 was isolated from the wood-fed treatment group. Based on the results of this study we propose that TI- $1^{\mathrm{T}}$ is the type strain of a new genus and species, Pilibacter termitis gen. nov., sp. nov.

Hydrolysis of bile aesculin, gelatin and urea, and production of indole from tryptophan, were determined using API 20AN systems (API bioMérieux). Production of acid from various carbon sources was determined using API $50 \mathrm{CH}$ systems in conjunction with API 50CHL medium (API bioMérieux). The cupules were overlaid with sterile mineral oil to maintain an anoxic environment. Results are given below.

Hydrolysis of hippurate was determined by using the method of Hwang \& Ederer (1975). Hydrolysis of DNA was determined by using DNase agar (Difco). Hydrolysis of starch was determined by the addition of soluble starch (Merck) to trypticase soy agar (TSA; Difco). Hydrolysis of L-pyrrolidonyl $\beta$-naphthylamide (PYR) was determined by using commercial PYR discs and reagents (Hardy). Susceptibility to bacitracin and optochin was determined using commercial discs (BBL Becton-Dickinson). Reduction of nitrates was determined by the use of nitrate reduction broth (Difco) supplemented with $0 \cdot 1 \%$ agar. Voges-Proskauer and methyl red tests were conducted in Voges-Proskauer broth supplemented with $0 \cdot 1 \%$ agar. Production of ammonia from arginine was determined using purple broth base (Difco) supplemented with $0.5 \%$ arginine (Fisher). Long-chain cellular fatty acid analysis was performed using the MIDI system (Sasser, 1997). Fermentation products were assayed using enzymic test kits for the detection of acetic acid, ethanol, formic acid, lactic acid and succinic acid (Boehringer Mannheim).

Determination of the DNA G $+\mathrm{C}$ content was performed by the Identification Services of the Deutsche Sammlung von Mikroorganismen und Zellkulturen (DSMZ) using the methods of Mesbah et al. (1989). DNA-DNA hybridization was also performed by the DSMZ; DNA obtained from $\sim 3 \mathrm{~g}$ (wet weight) of bacterial cell mass from strain TI- ${ }^{\mathrm{T}}$ was isolated using a French pressure cell (Thermo Spectronic) and was purified by chromatography on hydroxyapatite (Cashion et al., 1977). DNA-DNA hybridization was carried out as described by De Ley et al. (1970), with the modifications described by Huß et al. (1983), using a Cary 100 Bio UV/Vis spectrophotometer equipped with a Peltier-thermostatted $6 \times 6$ multicell changer and a temperature controller with in-situ temperature probe (Varian).

Scanning electron microscopy was performed by the Socolofsky Microscopy Facility at Louisiana State University, using cultures of strain TI- $1^{\mathrm{T}}$ fixed with $2 \%$ glutaraldehyde and $1 \%$ formaldehyde, post-fixed with $2 \%$ osmium tetroxide, rinsed, applied to graphite-coated specimen mounts, airdried, sputter coated and imaged with a Cambridge 260 scanning electron microscope.

DNA from bacterial colonies was isolated using a QIAGEN DNeasy Tissue kit. The 16S rRNA gene was amplified using the primer sets $8 \mathrm{~F}$ and $926 \mathrm{R}$ and $533 \mathrm{~F}$ and $1492 \mathrm{R}$ (Lane, 1991). Cycling conditions were as described by Hugenholtz et al. (1998). Sequencing was performed using a Beckman CEQ 2000 DNA analyser. The closest known relatives were identified by performing database searches using the National Center for Biotechnology Information (NCBI). Sequences were uploaded from NCBI, aligned using the CLUSTAL X program (Thompson et al., 1997) and edited manually using the BIOEDIT program (Hall, 1999). A phylogenetic tree was constructed with the neighbour-joining method of Felsenstein using the program NEIGHBOR (Felsenstein, 1989). Stability of the grouping was estimated using the programs DNABOOT, DNADIST, NEIGHBOR and CONSENSE with 1000 evaluations for bootstrapping (Felsenstein, 1989).

Strain TI- ${ }^{\mathrm{T}}$ grew readily on standard nutrient-rich laboratory media, including TSA, Todd-Hewitt agar and 5\% sheep's blood TSA. When grown on Todd-Hewitt agar for 3 days under anaerobic conditions at $30^{\circ} \mathrm{C}$, cells of strain TI$1^{\mathrm{T}}$ were found to be irregular Gram-positive rods. The rods typically occurred alone or in pairs and were often observed in palisade formations. They were variable in morphology with both regular rods and tapered, spindle-shaped forms occurring. A scanning electron micrograph of cells of strain TI $-1^{T}$ is shown in Fig. 1. The rods had a tendency to decolorize and often produced mixed Gram stains. In older cultures (i.e. more than 3 days) occasional swellings were observed in cells, particularly when grown on blood agar. Subsequent staining using the Schaeffer-Fulton method revealed that these swollen forms were not spores. The organism grew poorly under aerobic conditions both on solid media and in broth. Colonies grown aerobically on agar plates demonstrated marked reduction in colony size and were opaque, as compared with cream coloured when grown under anaerobic conditions. On $5 \%$ sheep's blood agar, alpha haemolysis was observed. Motility was not observed by using hanging drop suspensions and through inoculation into semi-solid thioglycollate media (BBL Becton-Dickinson).

The organism did not hydrolyse DNA, gelatin, hippurate, starch or PYR, or produce ammonia from arginine. The organism was positive for methyl red, negative for the Voges-Proskauer reaction and it was resistant to optochin at a concentration of $5 \mu \mathrm{g}$ per disc. Resistance to bacitracin 


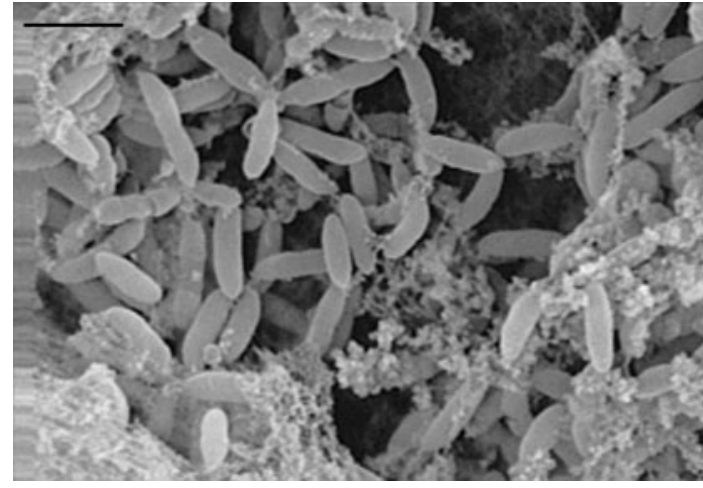

Fig. 1. Scanning electron micrograph of cells of Pilibacter termitis $\mathrm{TI}-1^{\top}$. Note that some cells display a curved morphology. Bar, $2 \mu \mathrm{m}$.

discs at a concentration of $0.05 \mathrm{IU}$ was variable. The organism failed to grow at $42{ }^{\circ} \mathrm{C}$ and did not grow in trypticase soy broth with $\mathrm{NaCl}$ concentrations of $6.5 \%$. The organism was catalase- and oxidase-negative. The major fermentation product of the organism was lactic acid $(8.03 \mathrm{mM})$ and the minor fermentation product was ethanol $(1 \cdot 15 \mathrm{mM})$. Acetic acid, succinic acid and formic acid were not detected as fermentation products. The DNA $\mathrm{G}+\mathrm{C}$ content of the organism was $37 \cdot 8 \mathrm{~mol} \%$.

Using API 20AN strips, aesculin was found to be hydrolysed but urea was not, and indole was not produced from tryptophan. Using API 50CH strips, acid was found to be produced from D-xylose, D-galactose, D-glucose, D-fructose, D-mannose, D-sorbitol, $N$-acetylglucosamine, amygdalin, arbutin, salicin, D-cellobiose, D-maltose, D-lactose, Dtrehalose and gentiobiose, but not from glycerol, erythritol, D-arabinose, L-arabinose, D-ribose, L-xylose, D-adonitol, Lsorbose, L-rhamnose, dulcitol, inositol, D-mannitol, methyl $\alpha$-D-mannopyranoside, methyl $\alpha$-D-glucopyranoside, Dmelibiose, sucrose, inulin, D-melezitose, D-raffinose, starch, glycogen, xylitol, D-turanose, D-lyxose, D-tagatose, D-fucose, L-fucose, D-arabitol, L-arabitol, potassium gluconate, potassium 2-ketogluconate or potassium 5-ketogluconate. The production of acid from methyl $\beta$-Dxylopyranoside was variable, with strain $\mathrm{TI}-1^{\mathrm{T}}$ testing negative and strains TI-2 and TI- 3 testing positive. Using API $50 \mathrm{CH}$, aesculin was found to be hydrolysed.

The predominant long-chain cellular fatty acids of the three strains were $\mathrm{C} 18: 1 \omega 9 c, \mathrm{C} 18: 1 \omega 9 c$ dimethyl aldehyde (DMA), C16:0, C14:0, a summed feature consisting of $\mathrm{C} 18: 1 \omega 7 c$ and the unknown fatty acid $\mathrm{C} 17 \cdot 834$, a summed feature consisting of $\mathrm{C} 17: 2$ and $\mathrm{C} 17: 1 \omega 9 c$, and $\mathrm{C} 16: 1 \omega 7 c$. Complete fatty acid profiles are given in Table 1 .

A phylogenetic tree was constructed using the neighbourjoining method with Bacillus subtilis selected as the outgroup (Fig. 2). The results of this tree demonstrate that, whereas strain $\mathrm{TI}-1^{\mathrm{T}}$ is related to other organisms within the order 'Lactobacillales', it forms a distinct branch from the
Table 1. Fatty acid compositions of Pilibacter termites strains

\begin{tabular}{|lccr|}
\hline Fatty acid & TI-1 $^{\text {T }}$ & TI-2 & TI-3 \\
\hline $\mathrm{C} 12: 0$ & $0 \cdot 58$ & - & $0 \cdot 30$ \\
$\mathrm{C} 14: 0$ & $9 \cdot 70$ & $8 \cdot 11$ & $8 \cdot 44$ \\
$\mathrm{C} 14: 1 \omega 5 c$ & - & $0 \cdot 41$ & $0 \cdot 45$ \\
$\mathrm{C} 15: 0$ & - & $0 \cdot 73$ & $0 \cdot 67$ \\
$\mathrm{C} 16: 0$ & $12 \cdot 57$ & $13 \cdot 71$ & $14 \cdot 72$ \\
$\mathrm{C} 16: 0$ aldehyde & $1 \cdot 17$ & $1 \cdot 23$ & $1 \cdot 31$ \\
$\mathrm{C} 16: 0$ DMA & $3 \cdot 03$ & $2 \cdot 89$ & $3 \cdot 21$ \\
$\mathrm{C} 16: 1 \omega 5 c$ & $0 \cdot 72$ & $0 \cdot 65$ & $0 \cdot 71$ \\
$\mathrm{C} 16: 1 \omega 7 c$ & $5 \cdot 48$ & $5 \cdot 31$ & $5 \cdot 13$ \\
$\mathrm{C} 16: 1 \omega 7 c$ DMA & - & - & $0 \cdot 51$ \\
$\mathrm{C} 18: 0$ & $1 \cdot 55$ & $1 \cdot 88$ & $1 \cdot 99$ \\
$\mathrm{C} 18: 1 \omega 7 c$ DMA & $1 \cdot 75$ & $1 \cdot 50$ & $1 \cdot 57$ \\
$\mathrm{C} 18: 1 \omega 9 c$ & $32 \cdot 25$ & $33 \cdot 91$ & $31 \cdot 43$ \\
$\mathrm{C} 18: 1 \omega 9 c$ DMA & $15 \cdot 37$ & $12 \cdot 59$ & $12 \cdot 12$ \\
$\mathrm{C} 18: 2 \omega 9 c$ DMA & - & $0 \cdot 89$ & $1 \cdot 99$ \\
Summed feature $7 *$ & $6 \cdot 53$ & $5 \cdot 66$ & $5 \cdot 31$ \\
Summed feature $10 \dagger$ & $9 \cdot 30$ & $10 \cdot 01$ & $10 \cdot 15$ \\
\hline
\end{tabular}

- , Not detected.

${ }^{\star} \mathrm{C} 17: 2 / \mathrm{C} 17: 1 \omega 9 c$.

†C18: $1 \omega 9 c /$ unknown $\mathrm{C} 17 \cdot 834$.

enterococci and the streptococci-lactococci branches. Strain TI $-1^{\mathrm{T}}$ shared greatest $16 \mathrm{~S}$ rRNA gene sequence similarity (99\%) with a culture-independent sequence of an undescribed bacterium cloned from gut samples of Coptotermes formosanus, clone BCf6-17 (GenBank accession no. AB062833). With recognized organisms, strain $\mathrm{TI}-1^{\mathrm{T}}$ was found to share greatest similarity with members of the genus Enterococcus (i.e. $92 \cdot 8 \%$ with Enterococcus saccharolyticus, $92.5 \%$ with Enterococcus gallinarum, $92.2 \%$ with Enterococcus hirae and $92.0 \%$ with Enterococcus faecalis). Data obtained from DNA-DNA hybridization indicates that strain TI- $1^{\mathrm{T}}$ had a DNA-DNA relatedness level of $31 \cdot 35 \%$ with E. faecalis DSM $20478^{\mathrm{T}}, 36 \cdot 65 \%$ with E. gallinarum DSM $2068^{\mathrm{T}}, 48 \cdot 3 \%$ with E. hirae DSM $20160^{\mathrm{T}}$ and $61 \cdot 2 \%$ with E. saccharolyticus DSM $20726^{\mathrm{T}}$. It has been postulated that members of the same genus share a sequence similarity of $>94 \%$ (Collins et al., 1994) or >97\% (Drancourt et al., 2000); these data, along with the low hybridization values and the distinct branching present in the phylogenetic tree, indicate that strain TI- $1^{\mathrm{T}}$ represents a member of a new genus.

Strain TI- $1^{\mathrm{T}}$ exhibits significantly different physiological characteristics from those associated with the genus Enterococcus. TI- $1^{\mathrm{T}}$ was found to have a cellular fatty acid profile different from those associated with the enterococci. A common fatty acid found in the enterococci is $\mathrm{C} 18: 1 \omega 7 c$, comprising $23 \%$ of the total fatty acids (Bosley et al., 1990). By contrast, $\mathrm{C} 18: 1 \omega 7 c$ formed only a minor component of the cellular fatty acids of strain TI- $1^{\mathrm{T}}(1 \cdot 75 \%$ of the total $)$. TI $-1^{\mathrm{T}}$ was also found to have high levels of the fatty acid C18: $1 \omega 9 c(32 \cdot 25 \%)$, whereas this fatty acid occurs at low 


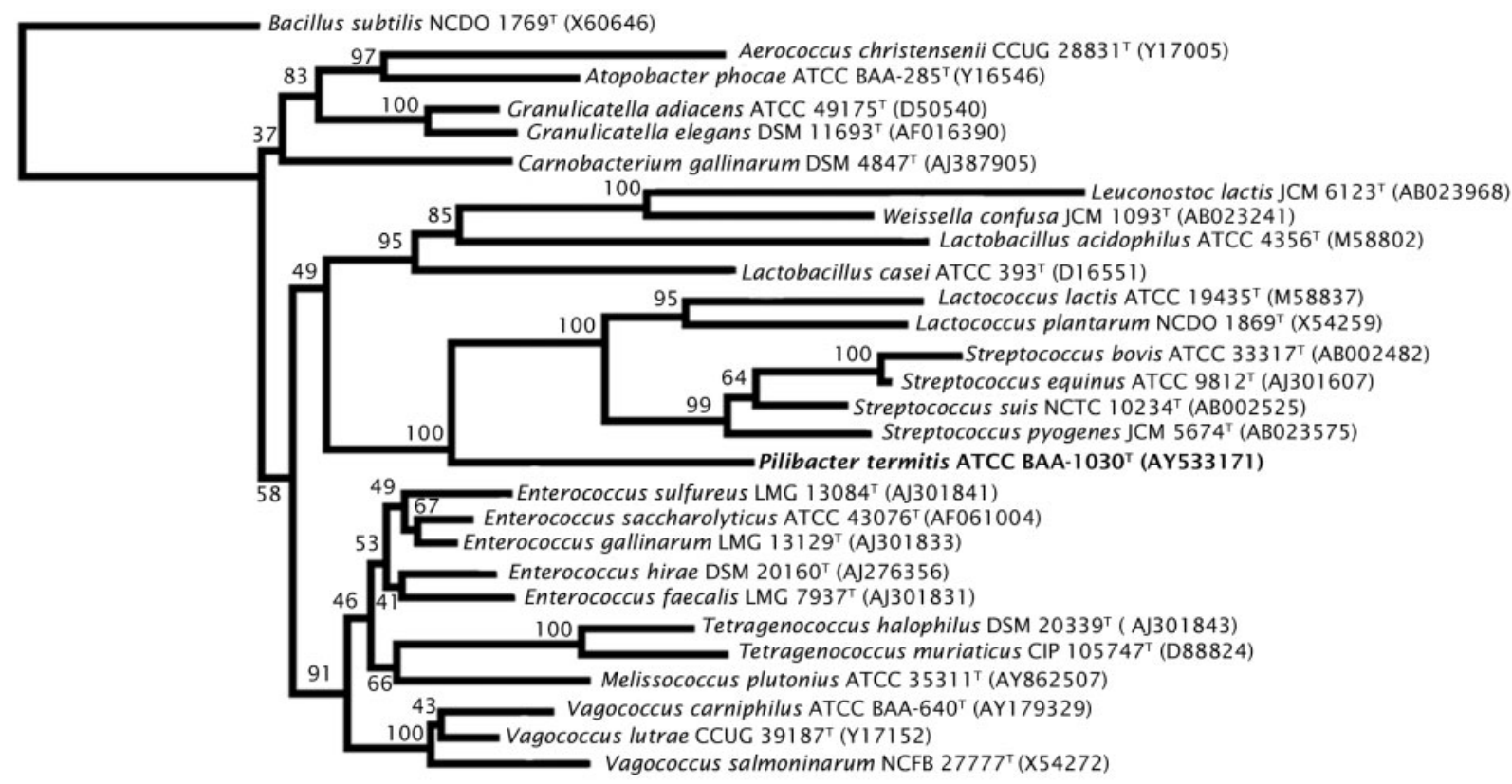

0.10

Fig. 2. Phylogenetic tree showing the relationship of Pilibacter termitis $\mathrm{TI}-1^{\top}$ with representative bacteria of the order 'Lactobacillales'. The tree was constructed by using the neighbour-joining method with Bacillus subtilis serving as the outgroup and is based on $1320 \mathrm{nt}$ aligned using CLUSTAL X. Bootstrap values are expressed as a percentage of 1000 replications and are indicated at branching points. Bar, $0 \cdot 10$ nucleotide substitutions per site.

levels in the cell membranes of the enterococci (1\%; Bosley et al., 1990). Production of ethanol in the fermentation of glucose by $\mathrm{TI}-1^{\mathrm{T}}$ is another key feature separating $\mathrm{TI}-1^{\mathrm{T}}$ from the homofermentative Enterococci (Stiles \& Holzapfel, 1997). Finally, TI- $1^{\mathrm{T}}$ tolerates oxygen poorly compared with most members of the genus Enterococcus. Several phenotypic characteristics may be used to separate TI $-1^{\mathrm{T}}$ from related species of Enterococcus. Specifically, these are negative results for hydrolysis of L-PYR, the Voges-Proskauer reaction and production of acid from L-arabinose, glycerol, mannitol, melibiose and sorbitol (Table 2). Based on the collected data, we propose that strain TI- $1^{\mathrm{T}}$ represents a novel species of a new genus, Pilibacter termitis gen. nov., sp. nov.

\section{Description of Pilibacter gen. nov.}

Pilibacter (Pi'li.bac.ter. L. neut. n. pilum a heavy javelin; N.L. masc. n. bacter from Gr. n. bakteron rod; N.L. masc. n. Pilibacter a rod that appears tapered and pointed, like the head of a spear).

Cells consist of non-motile, non-spore-forming irregular rods occurring alone, in pairs and in palisade formations. Rods are usually straight, but curved forms do occur and the rods typically appear tapered at the ends. Cells stain Gram-positive, but some have a tendency to lose colour, particularly when taken from older (over 3 days) colonies. Anaerobic growth is poor under ambient atmospheric conditions. Growth is observed at $20^{\circ} \mathrm{C}$ but not at $42^{\circ} \mathrm{C}$. The
DNA G $+\mathrm{C}$ content of the type strain of the type species is $37 \cdot 8 \mathrm{~mol} \%$, which indicates that this genus is member of the low-G + C-content Gram-positive bacteria. The major fermentation product is lactic acid with ethanol as a minor fermentation product. Pilibacter is a member of the order 'Lactobacillales' of the Gram-positive bacteria. The type species is Pilibacter termitis.

Table 2. Phenotypic characteristics that differentiate Pilibacter termitis gen. nov., sp. nov. from closely related species of Enterococcus

Species: 1, P. termitis; 2. E. faecalis; 3, E. gallinarum; 4, E. hirae; 5, E. saccharolyticus. Data for Enterococcus species were obtained from Devriese et al. (1993). Characteristics are scored as: + , positive; $\mathrm{D}$, different or variable; $\mathrm{D}+$, usually positive; - , negative.

\begin{tabular}{|lccccc|}
\hline Characteristic & $\mathbf{1}$ & $\mathbf{2}$ & $\mathbf{3}$ & $\mathbf{4}$ & $\mathbf{5}$ \\
\hline Pyrrolidonyl arylamidase & - & + & + & + & - \\
Voges-Proskauer reaction & - & + & + & + & - \\
Acid from: & & & & & \\
$\quad$ L-Arabinose & - & - & + & - & - \\
Glycerol & - & + & - & - & - \\
Mannitol & - & + & + & - & + \\
Melibiose & - & - & + & + & + \\
Sorbitol & - & $\mathrm{D}+$ & $\mathrm{D}$ & - & + \\
\hline
\end{tabular}




\section{Description of Pilibacter termitis sp. nov.}

Pilibacter termitis (ter'mi.tis. L. n. termes a worm that eats wood, a woodworm, and in zoology the scientific name of a genus of termite; N.L. gen. n. termitis of a termite).

Has the following characteristics in addition to those given above for the genus. Colonies are cream coloured and alphahaemolytic when grown on blood agar. Anaerobic. Catalaseand oxidase-negative. No growth is observed in $6.5 \% \mathrm{NaCl}$. Nitrates are not reduced. Aesculin is hydrolysed but not DNA, gelatin, hippurate, starch, urea or L-PYR. Positive for methyl red but negative for the Voges-Proskauer reaction. Indole is not produced from tryptophan. Resistant to optochin. Susceptibility to bacitracin varies. Acid is produced from D-xylose, D-galactose, D-glucose, D-fructose, D-mannose, D-sorbitol, $\mathrm{N}$-acetylglucosamine, amygdalin, arbutin, salicin, D-cellobiose, D-maltose, D-lactose, Dtrehalose and gentiobiose, but not from glycerol, erythritol, D-arabinose, L-arabinose, D-ribose, L-xylose, D-adonitol, Lsorbose, L-rhamnose, dulcitol, inositol, D-mannitol, methyl $\alpha$-D-mannopyranoside, methyl $\alpha$-D-glucopyranoside, Dmelibiose, sucrose, inulin, D-melezitose, D-raffinose, starch, glycogen, xylitol, D-turanose, D-lyxose, D-tagatose, D-fucose, L-fucose, D-arabitol, L-arabitol, potassium gluconate, potassium 2-ketogluconate or potassium 5-ketogluconate. The production of acid from methyl $\beta$-Dxylopyranoside is variable. The major long-chain fatty acids are $\mathrm{C} 16: 0, \mathrm{C} 18: 1 \omega 9 c$ and $\mathrm{C} 18: 1 \omega 9 c$ DMA.

The type strain is TI $-1^{\mathrm{T}}\left(=\right.$ ATCC BAA- $1030^{\mathrm{T}}=\mathrm{CCUG}$ $49613^{\mathrm{T}}$ ), isolated from the hindgut of the Formosan subterranean termite, Coptotermes formosanus Shiraki (Isoptera: Rhinotermitidae).

\section{Acknowledgements}

The authors would like to thank Mr Brian Rash of the LSU Department of Biological Sciences for his gracious assistance with the construction of Fig. 2. We are indebted to Ms Margaret C. Henk at the Socolofsky Microscopy Center, at the LSU Department of Biological Sciences, for Fig. 1. We would like to extend our gratitude to Dr Stuart Donachie of the Department of Microbiology at UH-Manoa for his expert technical advice. Finally we would like to thank Dr J. P. Euzéby of the École Nationale Vétérinaire for his kind help in devising a proper scientific name for the bacterium described here. This is journal series no. 04-260645 of the Louisiana Agricultural Experiment Station, Louisiana State University Agricultural Center. Funding was partially provided by USDA-ARS Specific Cooperative Agreement no. 58-6615-4-237 and Louisiana Board of Regents Agreement no. LEQSF (2004-07)-RD-A-01.

\section{References}

Bauer, S., Tholen, A., Overmann, J. \& Brune, A. (2000). Characterization of abundance and diversity of lactic acid bacteria in the hindgut of wood- and soil-feeding termites by molecular and culture-dependent techniques. Arch Microbiol 173, 126-137.

Bosley, G. S., Wallace, P. L., Moss, W., Steigerwalt, A. G., Brenner, D. J., Swenson, J. M., Hebert, G. A. \& Facklam, R. R. (1990). Phenotypic characterization, cellular fatty acid composition, and
DNA relatedness of aerococci and comparison to related genera. J Clin Microbiol 28, 416-421.

Cashion, P., Holder-Franklin, M. A., McCully, J. \& Franklin, M. (1977). A rapid method for the base ratio determination of bacterial DNA. Anal Biochem 81, 461-466.

Collins, M. D., Lawson, P. A., Willems, A., Cordoba, J. J., FernandezGarayzabal, J., Garcia, P., Cai, J., Hippe, H. \& Farrow, J. A. E. (1994). The phylogeny of the genus Clostridium: proposal of five new genera and eleven new species combinations. Int J Syst Bacteriol 44, 812826.

De Ley, J., Cattoir, H. \& Reynaerts, A. (1970). The quantitative measurement of DNA hybridization from renaturation rates. Eur J Biochem 12, 133-142.

Devriese, L. A., Pot, B. \& Collins, M. D. (1993). Phenotypic identification of the genus Enterococcus and differentiation of phylogenetically distinct enterococcal species and species groups. J Appl Bacteriol 75, 399-408.

Drancourt, M., Bollet, C., Carlioz, A., Martelin, R., Gayral, J.-P. \& Raoult, D. (2000). 16S ribosomal DNA sequence analysis of a large collection of environmental and clinical unidentifiable bacterial isolates. J Clin Microbiol 38, 3623-3630.

Eutick, M. L., O’Brien, R. W. \& Slaytor, M. (1978). Bacteria from the gut of Australian termites. Appl Environ Microbiol 35, 823-828.

Felsenstein, J. (1989). PHYLIP - Phylogenetic Inference Package, version 3.5. Distributed by the author. Department of Genome Sciences, University of Washington, Seattle, USA.

Hall, T. A. (1999). BIOEDIT: a user-friendly biological sequence alignment editor and analysis program for Windows 95/NT. Nucleic Acids Symp Ser 41, 95-98.

Hugenholtz, P., Pitulle, C., Hershberger, K. L. \& Pace, N. R. (1998). Novel division level bacterial diversity in a Yellowstone hot spring. J Bacteriol 180, 366-376.

Huß, V. A. R., Festl, H. \& Schleifer, K. H. (1983). Studies on the spectrophotometric determination of DNA hybridization from renaturation rates. Syst Appl Microbiol 4, 184-192.

Hwang, M. \& Ederer, G. M. (1975). Rapid hippurate hydrolysis method for the presumptive identification of group B streptococci. J Clin Microbiol 1, 114-115.

Kane, M. D. \& Breznak, J. A. (1991). Acetonema longum gen. nov. sp. nov., an $\mathrm{H}_{2} / \mathrm{CO}_{2}$ acetogenic bacterium from the termite, Pterotermes occidentus. Arch Microbiol 156, 91-98.

Lane, D. J. (1991). 16S/23S rRNA sequencing. In Nucleic Acid Techniques in Bacterial Systematics, pp. 115-175. Edited by E. Stackebrandt \& M. Goodfellow. New York: Wiley.

Mesbah, M., Premachandran, U. \& Whitman, W. B. (1989). Precise measurement of the $\mathrm{G}+\mathrm{C}$ content of deoxyribonucleic acid by high-performance liquid chromatography. Int J Syst Bacteriol 38, 159-167.

Ohkuma, M. \& Kudo, T. (1996). Phylogenetic diversity of the intestinal bacterial community in the termite Reticulitermes speratus. Appl Environ Microbiol 62, 461-468.

Sasser, M. (1997). Identification of bacteria by gas chromatography of cellular fatty acids. MIDI Technical Note 101. Newark, DE: MIDI.

Schultz, J. E. \& Breznak, J. A. (1978). Heterotrophic bacteria present in the hindguts of wood-eating termites [Reticulitermes flavipes (Kollar)]. Appl Environ Microbiol 35, 930-936.

Schultz, J. E. \& Breznak, J. A. (1979). Cross-feeding of lactate between Streptococcus lactis and Bacteroides sp. isolated from termite hindguts. Appl Environ Microbiol 37, 1206-1210.

Stiles, M. E. \& Holzapfel, W. H. (1997). Lactic acid bacteria of foods and their current taxonomy. Int J Food Microbiol 36, 1-29. 
Thompson, J. D., Gibson, T. J., Plewniak, F., Jeanmougin, F. \& Higgins, D. G. (1997). The CLUSTAL_X windows interface: flexible strategies for multiple sequence alignment aided by quality analysis tools. Nucleic Acids Res 25, 4876-4882.
Trinkerl, M., Breunig, A., Schauder, R. \& Konig, H. (1990). Desulfovibrio termitidis sp. nov., a carbohydrate-degrading sulfatereducing bacterium from the hindgut of a termite. Syst Appl Microbiol 13, 372-377. 